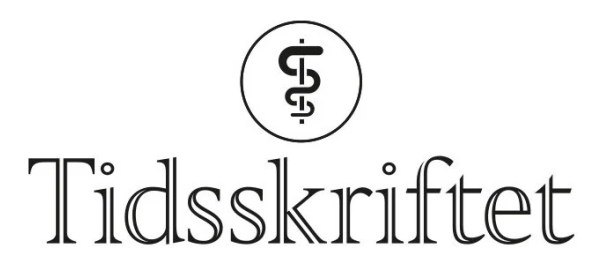

DEN NORSKE LEGEFORENING

\title{
Må psykiatere være dydige?
}

\section{ANMELDELSER}

TORE GUDE

Modum Bad

og

Avdeling for atferdsfag

Universitetet i Oslo

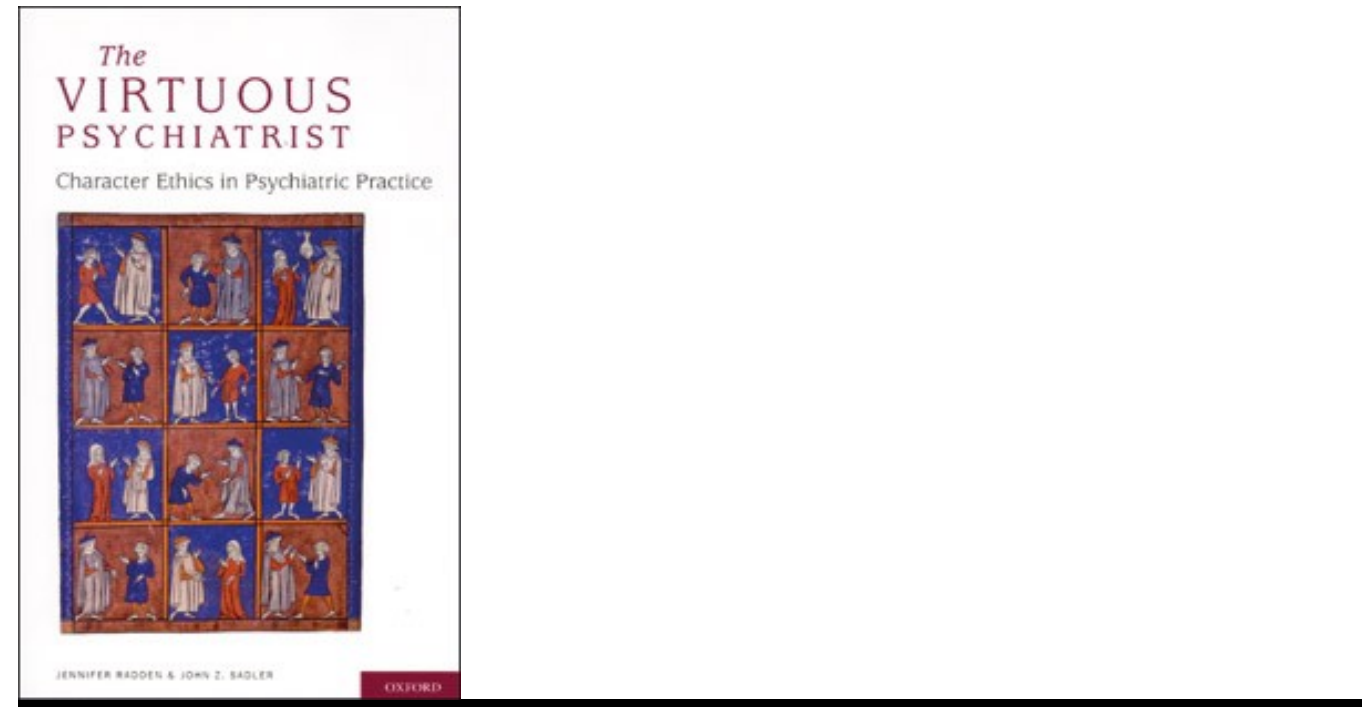

Radden, Jennifer

Sadler, Johan

The virtuous psychiatrist

Character ethics in psychiatric practice. 240 s. Oxford: Oxford University Press, 2010.

Pris GBP 33

ISBN 978-0-19-538937-1

Hvordan skal begrepet "the virtuous psychiatrist» oversettes til norsk? Den mest nærliggende oversettelsen av det engelske ordet «virtuous» er «dydig», men det gir ikke åpenbar mening i denne sammenhengen. Det forfatterne belyser, er et sentralt tema innen 
medisinen generelt og psykiatrien spesielt, om den etiske ballasten som trengs for å utøve faget rettmessig. Kanskje rettmessig eller enda bedre, rettskaffen, kan være en forståelig oversettelse av «virtuous».

Den rettskafne psykiater, hvilke utfordringer vil hun/han møte i sin yrkeskarriere som er spesielle og annerledes enn i medisinen for øvrig? Forfatterne beskriver hvordan psykiateren må forholde seg til, og utøve sin faglighet overfor, mennesker med alvorlige psykiske lidelser som av og til må behandles mot sin vilje - fordi de ikke er i stand til å ta hånd om sin egen tilværelse. Hva kreves av slike yrkesroller for at faglig forsvarlighet kan opprettholdes, at psykiateren ikke prøver å tilfredsstille egne behov på bekostning av pasientene? Og hva er spesielt for disse pasientene? Dette prøver forfatterne å gi svar på, i løpet av de åtte kapitlene, ved å kombinere filosofi og egen klinisk erfaring. Deres utgangspunkt er at søkelyset i for liten grad er rettet mot dette temaet og at temaet er for lite diskutert i fagkretser og i litteraturen, derfor vil de sette det på dagsorden.

En god psykiater trenger, ifølge forfatterne, en vedvarende oppmerksomhet på de moralske aspektene ved sin psykologiske og medisinske forståelse av sine pasienter, som er spesielt sårbare. Deres sykdomstilstand kan i høyere grad enn hos somatiske pasienter utvikle seg til en kronisk lidelse, i tillegg til at de fortsatt utsettes for stigmatisering fra samfunnet. Spesielt for psykiateren er også at i behandlingssammenheng er forholdet mellom pasient og terapeut av helt vesentlig betydning og avgjørende for forløp og utfall av behandlingen mer enn i somatisk medisin.

Dermed er psykiaterens evne til å beherske relasjonsaspektet av vital betydning, det gjelder hvorvidt kjønnsaspektet (om pasient og terapeut er av samme eller motsatt kjønn), seksuell legning, sosial klasse og etnisk tilhørighet gir terapeuten spesielle utfordringer og kan sette vedkommendes kompetanse på strekk. I norsk psykiatri har denne erkjennelsen medført at veiledning er en bærebjelke i spesialistutdanningen, med obligatoriske krav i spesialistreglene om både regelmessig klinisk veiledning og psykoterapiveiledning.

Forfatterne gir mye plass til å omtale sentrale karaktertrekk hos den rettskafne psykiater. Det dreier seg bl.a. om pålitelighet, nøyaktighet, ærlighet, omsorgsevne, velvillighet, empatisk kompetanse og integritet, sistnevnte kan ses som en syntese av de foregående. Alle disse karaktertrekkene er det ikke vanskelig å være enig med dem i at kan være idealer å strekke seg etter. Forfatterne hevder at mye av dette kan trenes opp gjennom bevisstgjøring og tilvenning (habituering), selv om ikke alle av oss har disse egenskapene som naturgitte. Hvordan dette gjøres, blir imidlertid vel filosofisk vinklet med stadige henvisninger til Aristoteles og hans tenkning. Her savner jeg en mer pragmatisk klinisk tilnærming, noe de få kliniske eksemplene ikke dekker opp for.

Et så «tungt» tema, som attpåtil formidles i en filosofisk stil og på et fremmed språk, er det vanskelig å opparbeide en glød for. Denne boken blir nok ingen bestselger - selv om temaet kunne ha gjort den fortjent til det.

Publisert: 21. februar 2012. Tidsskr Nor Legeforen. DOI: 10.4045/tidsskr.11.1423

(C) Tidsskrift for Den norske legeforening 2023. Lastet ned fra tidsskriftet.no 26. april 2023. 